\title{
QUESTIONNAIRE FOR POTENTIAL REVIEWERS
}

Insofar as possible the Editors will select reviewers from among readers of the JOURNAL. They therefore request all who would be willing to write reviews to fill out and return this form to The Editors, JOURNAL OF ECONOMIC HISTORY, University of Pennsylvania, 3718 Locust Walk, Philadelphia, Pennsylvania 19104.

Name (last name first):

Address:

Institutional affiliation (if not in address) and academic status:

Areas of reviewing competence in economic history (specify country and place):

Languages other than English in which you have a reading proficiency:

Representative recent publications (maximum of five): 


\section{A few enterprising individuals established the character of American business...}

\begin{abstract}
The Vital Few, a study of the contribution entrepreneurs have made to the American economy, provides portraits of these business mavericks and offers insights into the qualities required of America's superachievers. For the expanded edition, Jonathan Hughes has added to his list of Eli Whitney, Henry Ford, and others two "bureaucratic entrepreneurs"-Mary Switzer and Marriner Eccles-whose stories illuminate the nature of today's business environment.
\end{abstract}

\section{On the first edition:}

"A landmark in American intellectual history."

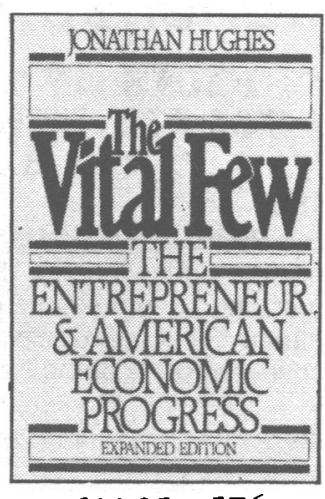

$\$ 11.95576 \mathrm{pp}$.

-W.F Rickenbacker, National Review

"[Hughes's] biographical chapters... are excellent. They show wide reading, careful research, a lively and curious mind."-H.G.L. Aitken, American Economist

Available at better bookstores or directly from:

OXFORD PAPERBACKS • Oxford University Press

200 Madison Avenue $\cdot$ New York, NY 10016

\section{PIONEERING ECONOMIC THEORY, 1630-1980 A Mathematical Restatement} BY HANS BREMS

$I_{\mathrm{n}}$ a tour de force both sweeping and elegant, Hans Brems charts the evolution of economic thought from 1630 to the present. Applying current theory and mathematics to the ideas of earlier periods, Brems provides rich new insights for economics past and present.

After surveying the history and principal economic themes of a period, Brems offers intensive explications of individual thinkers, quoting directly from their works and reformulating their theories in current mathematical terms. He not only elucidates particular ideas but demonstrates their relationship to economic theory today.

$\$ 45.00$

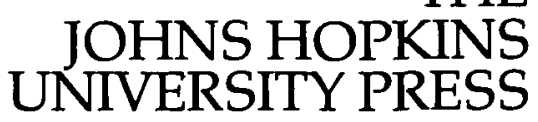

701 West 40th Street, Suite 275, Baltimore, Maryland 21211 


\section{Economic History from ORIGINS OF THE FEDERAL RESERVE SYSTEM}

Money, Class, and Corporate Capitalism. 1890-1913

By JAMES LIVINGSTON. The rise of corporate capitalism during the late 19 th and early 20 th centuries has long been a source of lively debate among historians. This interdisciplinary account seeks to uncover the roots of the Federal Reserve System and to explain the awakening and articulation of class consciousness among America's urban elite.

$\$ 27.50$

\section{EMPIRES}

By MICHAEL W. DOYLE. "Doyle puts forward an intriguing set of arguments about the sources of imperialism in a social-scientific way. His work is erudite, broad in scope, theoretically sophisticated, and thoughtful as well as thought-provoking."Robert O. Keohane, Harvard. (Cornell Studies in Comparative History) $\$ 14.95$ paper; $\$ 42.50$ cloth

\section{WORK IN FRFNCE}

Representations, Meaning, Organization, and Practice

Edited by STEVEN LAURENCE KAPLAN and CYNTHIA J. KOEPP. Scholars from both sides of the Atlantic look at the question of work across three centuries of French history. Contributors: Ronald Aminzade, Patrick Fridenson, Maurice Garden, Michael P. Hanagan, Christopher H. Johnson, Yves Lequin, Michelle Perrot, Anson Rabinbach, Jacques Rancière, William M. Reddy, Daniel Roche, Joan W. Scott, William H. Sewell, Jr., Edward J. Shephard, Jr., Michael Sonenscher, Cynthia M. Truant, and the editors.

$\$ 42.50$

\section{PROVISIONING PARIS}

Merchants and Millers in the Grain and Flour Trade during the Eighteenth Century By STEVEN L. KAPLAN. "A highly thoughtful and readable work. . . . A book which will be of great interest to students of the French Revolution as well as of eighteenth-century social and economic life." -Patrice Higonnet, Harvard. "An immensely erudite study."-Times Literary Supplement.

$\$ 39.95$

\section{CORNILL. UNIVERSITY PRESS}

P.O. Box 250, Ithaca, New York 14851

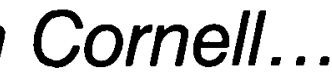

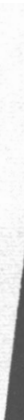

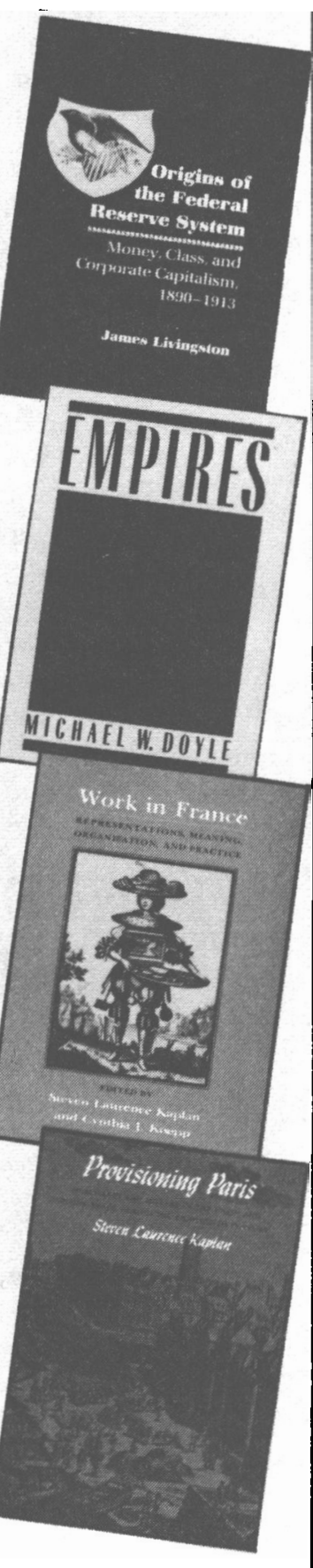




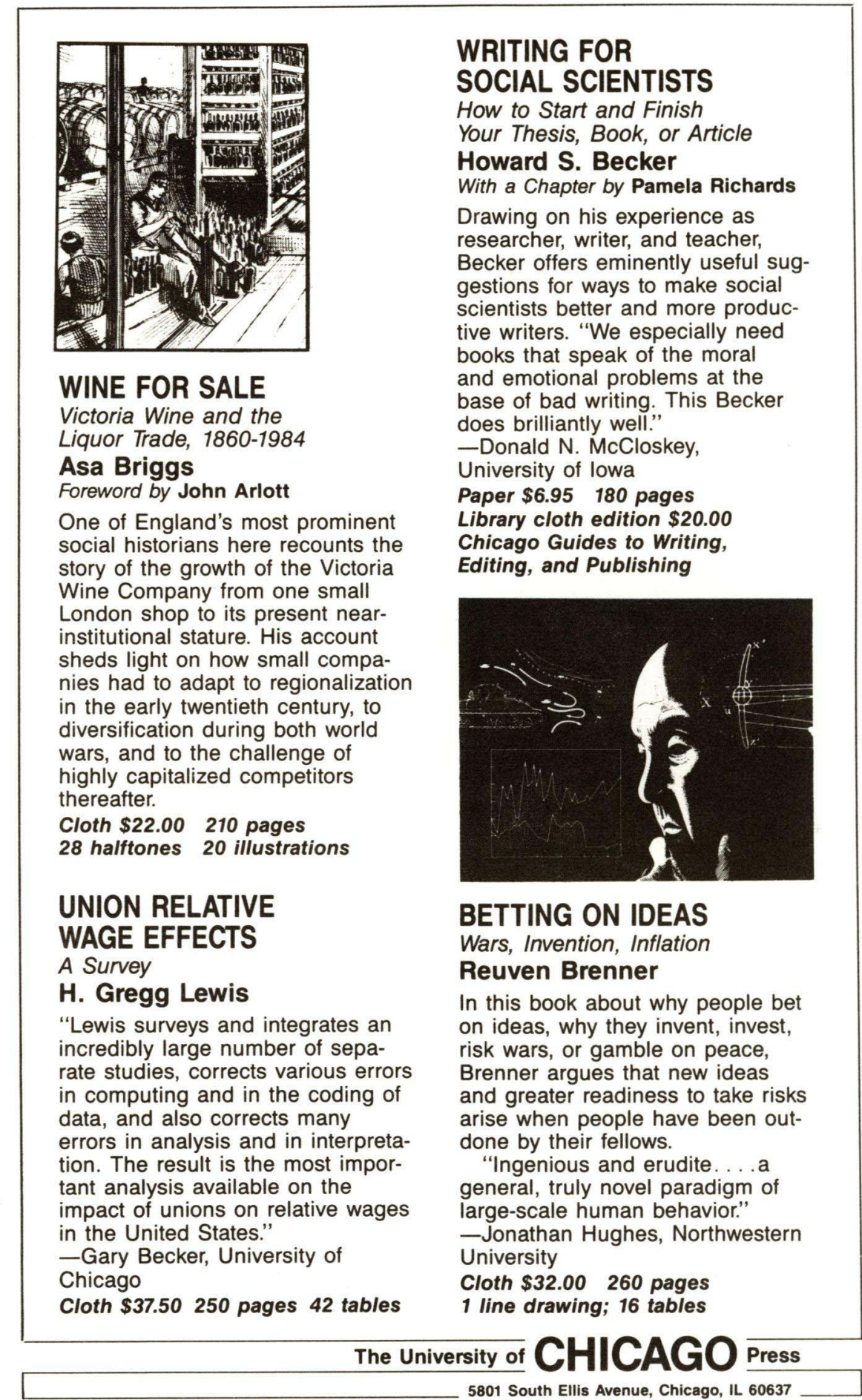




\section{New Paperbacks from Cambridge}

\section{Out of Work}

The First Century of Unemployment in Massachusetts Alexander Keyssar

"This book will prove, I think, to be a seminal work in economic and social history... The evaluation of evidence amassed here and the conclusions drawn from it will occupy a generation of scholars. But the book should also have an immediate impact upon contemporary policy debates about what to do about unemployment." - Michael Piore,

Massachusetts Institute of Technology

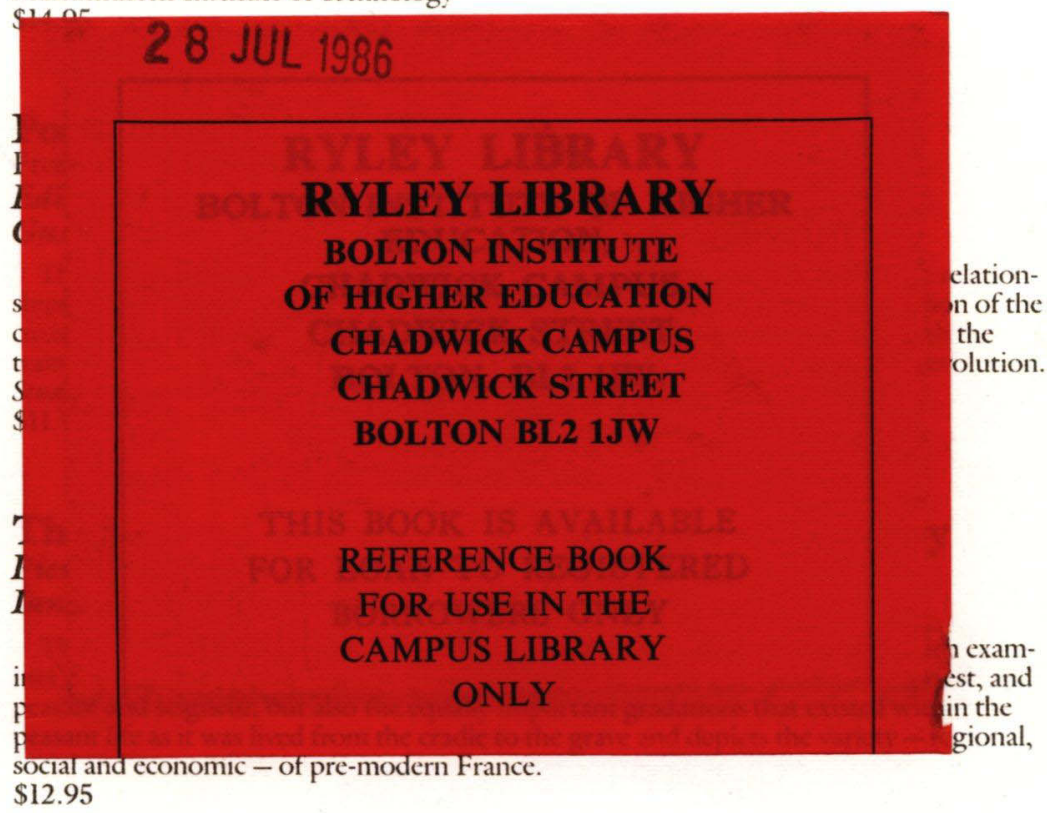

\section{Trade and Civilisation in the Indian Ocean}

\section{An Economic History from the Rise of Islam to 1750}

\section{K.N. Chaudhuri}

Professor Chaudhuri's book, based on more than twenty years of research and reflection on premodern trade and civilizations, is a landmark in the analysis and interpretation of Asia's historical position and development. $\$ 16.95$

\section{CAMBRIDGE UNIVERSITY PRESS}

32 East 57th Street, New York, NY 10022

800-431-1580 (outside New York State and Canada) MasterCard and Visa accepted 